\title{
The Woodland Period Component at the Wolfshead Site (41SA117), San Augustine County, Texas
}

Timothy K. Perttula

Heritage Research Center, Stephen F. Austin State University

Mark Walters

Heritage Research Center, Stephen F. Austin State University

Follow this and additional works at: https://scholarworks.sfasu.edu/ita

Part of the American Material Culture Commons, Archaeological Anthropology Commons, Environmental Studies Commons, Other American Studies Commons, Other Arts and Humanities Commons, Other History of Art, Architecture, and Archaeology Commons, and the United States History Commons

Tell us how this article helped you.

This Article is brought to you for free and open access by the Center for Regional Heritage Research at SFA ScholarWorks. It has been accepted for inclusion in Index of Texas Archaeology: Open Access Gray Literature from the Lone Star State by an authorized editor of SFA ScholarWorks. For more information, please contact cdsscholarworks@sfasu.edu. 


\section{The Woodland Period Component at the Wolfshead Site (41SA117), San Augustine County, Texas}

\section{Creative Commons License}

\section{(c) (1) (8)}

This work is licensed under a Creative Commons Attribution-NonCommercial 4.0 International License 


\title{
The Woodland Period Component at the Wolfshead Site (41SA117), San Augustine County, Texas
}

\author{
Timothy K. Perttula and Mark Walters
}

\section{INTRODUCTION}

The Wolfshead site (41SA117) was excavated by the Texas Archeological Salvage Project at The University of Texas in the fall and winter of 1960 prior to the inundation of the site by the waters of Lake Sam Rayburn in the Angelina River basin in East Texas (Duffield 1963). The site was located on a sandy terrace and covered ca. 1 acre in size; the sandy deposits were a maximum of ca. $60 \mathrm{~cm}$ in thickness below an historic plow zone (Duffield 1963:Figure 2).

The excavations were in the northern and southern parts of the site (see Duffield 1963:Figure 3), and indicated that the Wolfshead site had an extensive Late Paleoindian-Early Archaic San Patrice culture occupation dating ca. 10,500-9800 years B.P., as well as a Woodland period (ca. 2500-1150 years B.P.) occupation in both site areas. The latter occupation is a component of the inland and deep East Texas Mossy Grove culture defined by Story (1990). This component is recognized by the occurrence of sandy paste Goose Creek Plain ceramic vessel sherds, contracting stem dart points (in the earlier part of the Woodland period), and various stemmed arrow points (after ca. A.D. 700 in the Woodland period).

\section{Ceramic Sherd Assemblage}

The Woodland period ceramic sherd assemblage from the Wolfshead site in the collections of the Texas Archeological Research Laboratory at The University of Texas at Austin is comprised of 423 sherds from non-tempered sandy paste vessels and two sherds from bone-tempered sandy paste vessels (Table 1). The undecorated sherds are from Goose Creek Plain, var. unspecified vessels (see Aten and Bollich 2011:156157). The rims are direct and have a rounded lip, indicating they are from unrestricted vessels, likely bowls and jars (see Duffield 1963:Figure 17).

Table 1. Sandy paste ceramic sherd assemblage from the Wolfshead site.

\begin{tabular}{llllll}
\hline Ware & Plain rim & Plain body & Incised-Punctated & Incised & $\mathrm{N}$ \\
\hline $\begin{array}{l}\text { Sandy paste } \\
\begin{array}{l}\text { Sandy paste- } \\
\text { bone- }\end{array}\end{array}$ & 26 & $392^{*}$ & 4 & 1 & 423 \\
tempered & 2 & - & - & 2 \\
\hline Totals & 26 & 394 & 4 & & \\
\hline
\end{tabular}

*one sherd with a drilled suspension hole

Coarse sandy paste sherds - called East Texas Ironware by Webb et al. (1969) because of their sandpaper-like texture - are a characteristic material culture feature of Woodland period occupations in the southern part of East Texas (i.e., south and west of the Sabine River to as far west as the Trinity River and Brazos River valleys). They also occur in abundance in Southeast Texas sites as far south as the Gulf Coast (Aten and Bollich 2011). As previously mentioned, these Woodland period sites are part of the Mossy Grove Culture defined by Story (1990:Figure 39) and including specifically the Neches-Angelina area. 
Only 1.2 percent of the sandy paste sherds from the site are from decorated vessels, either bowls or jars. Four body sherds have zoned incised-punctated decorative elements, including three sherds with a narrow incised panel filled with small tool punctations (Figure1a). The other incised-punctated body sherd has both curvilinear and parallel incised panels filled with small tool punctations (Figure 1b, see also Duffield 1963:Figure 18). These sherds may be from an undefined variety of Orleans Punctated, or an as yet undefined late Woodland incised-punctated ware. The other decorated sandy paste sherd from the Wolfshead site is a cf. Goose Creek Incised, var. Goose Creek (Aten and Bollich 2011:157) body sherd with cross-hatched incised lines. Comparable incised and incised-punctated decorative elements are recognized in later (after ca. A.D. 850) grog- and bone-tempered ancestral Caddo ceramic vessels and vessel sherds in many East Texas Caddo sites, as well as in Woodland period components in the Angelina River basin.

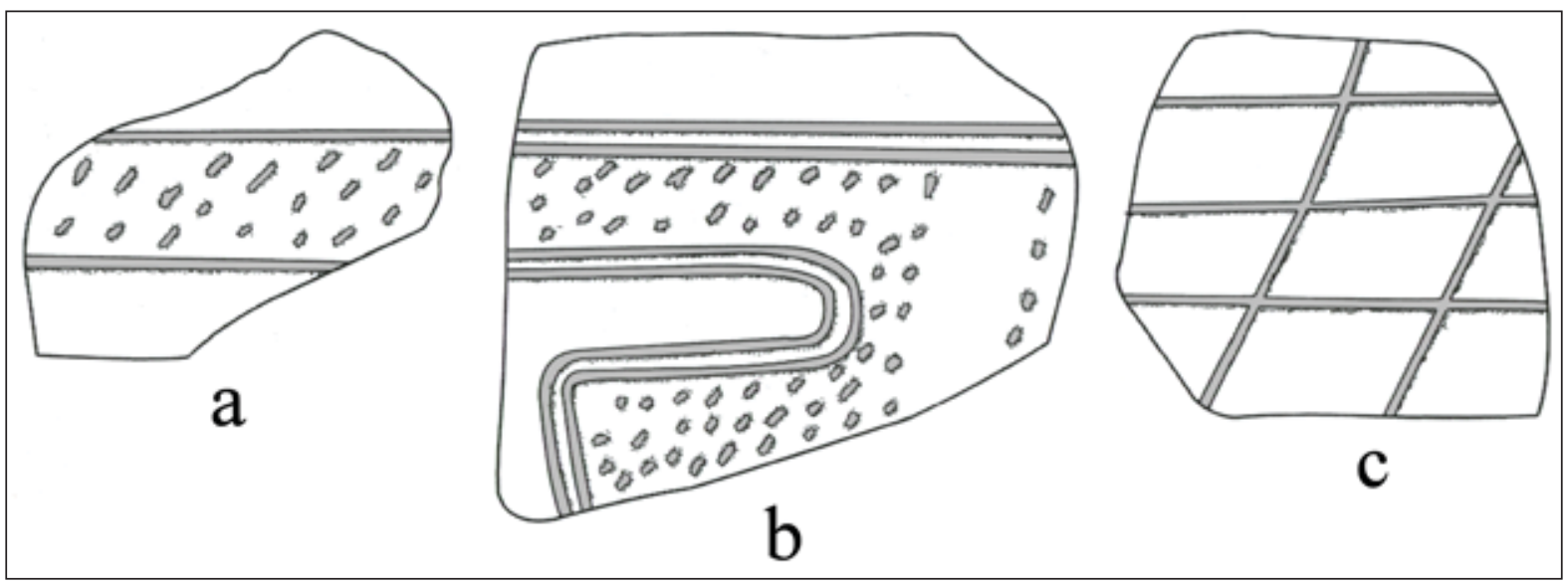

Figure 1. Decorated sandy paste sherds from the Wolfshead site: $a-b$, incised-punctated body sherds; $c$, cross-hatched incised body sherd.

Although decorated sandy paste sherds of the Goose Creek Plain ware are rare, they do occur to some small extent in East Texas Woodland period Mossy Grove sites (see Story 1990:Tables 58 and 64), including 11 decorated sherds from the Runnels No. 1 (41SA87), Print Bell (41SB36), and Jonas Short (41SA101) sites at Lake Sam Rayburn (Jelks 1965:117; Tunnell 1961). For instance, such decorated sherds are recognized in the Lake Naconiche sites in the Angelina River basin - particularly the Naconiche Creek (41NA236) and Boyette (41NA285) sites - where both incised and incised-punctated decorative elements were particularly common (Perttula 2008); however, the overall proportion of decorated sherds in these assemblages was only about 3 percent. Such decorated sherds are most common in the Woodland period component at the Boyette site that has calibrated 2 sigma radiocarbon dates that range from A.D. 643-882 (Perttula 2013:Table 1).

\section{Lithic Tools}

Late Woodland period lithic tools at the Wolfshead site include Friley $(n=4)$ and Scallorn $(n=6)$ arrow points, the earliest of the arrow point forms in East Texas, dating after ca. A.D. 700 into the $9^{\text {th }}$ century A.D. (Shafer and Walters 2010). The Friley points are made from local petrified wood and red chert raw materials, but 33 percent of the Scallorn points are on non-local gray chert and jasper that would have been available in Red River gravels. The remainder of the Scallorn points are made from local petrified wood. 


\section{SUMMARY AND CONCLUSIONS}

The Mossy Grove Culture Woodland period groups that lived in East Texas, and in the Angelina River basin, were relatively parochial hunting-gathering foragers with a mobile settlement system characterized by intermittently occupied camps, and a material culture dominated by plain sandy paste pottery, dart points and bifaces, arrow points after ca. A.D. 700, and expedient tools. The Woodland period occupation at the Wolfshead site (41SA117) at Lake Sam Rayburn is one such Mossy Grove culture component.

The Mossy Grove component at the Wolfshead site is best known through its sandy paste Goose Creek Plain ceramic vessel sherd assemblage, although there are a few early stemmed arrow point forms also in the collection. There are no Lower Mississippi Valley style plain or decorated sherds in the assemblage. The sherd assemblage at the Wolfshead site is characterized by plain rim and body sherds from sandy paste and bone-tempered sandy paste (representing only 0.2 percent of the sherd sample) vessels, and only 1 percent of the sandy paste sherds in the assemblage are decorated. The frequency of decorated sandy paste wares seems to have increased by the time of the $7^{\text {th }}$ century A.D. occupation at sites in the Angelina River basin and the decorated sandy paste sherds include simple straight and geometric decorative elements made with incised, incised-punctated, and punctated decorative methods. The few decorated sandy paste sherds, and the arrow point forms, at the Wolfshead site suggest that the occupation there took place sometime after the $7^{\text {th }}$ century A.D.

The manufacture and use of sandy paste Goose Creek Plain ceramic vessels in Woodland period sites in East Texas seems to have remained relatively and remarkably unchanged through more than 1000 years, until the latter part of the $7^{\text {th }}$ century A.D., when some vessels began to be decorated with simple decorative elements before vessels were fired. The same vessel forms (simple bowls and jars) were made throughout that span of time, and there is no evidence in the East Texas archaeological record to suggest that these vessels began to be made, or changed in any respect (except perhaps in their decoration), due to the adoption of new food stuffs or new forms of cooking technology

\section{ACKNOWLEDGMENTS}

Lance Trask prepared Figure 1 for this article. The staff at the Texas Archeological Research Laboratory, particularly Marybeth Tomka, facilitated our access to the collections for analyses.

\section{REFERENCES CITED}

Aten, L. E. and C. N. Bollich

2011 Early Ceramic Sites of the Sabine Lake Area, Coastal Texas and Louisiana. Studies in Archeology 43. Texas Archeological Research Laboratory, The University of Texas at Austin.

Duffield, L. F.

1963 The Wolfshead Site: An Archaic-Neo-American Site in San Augustine County, Texas. Bulletin of the Texas Archeological Society 34:83-141.

Jelks, E. B.

1965 The Archeology of McGee Bend Reservoir, Texas. Ph.D. dissertation, Department of Anthropology, The University of Texas at Austin.

Perttula, T. K.

2013 Woodland Period Archaeology as seen from the Attoyac Bayou Basin in East Texas. Caddo Archeology Journal 23:5-26. 
Perttula, T. K. (editor)

2008 Lake Naconiche Archeology, Nacogdoches County, Texas: Results of the Data Recovery Excavations at Five Prehistoric Archeological Sites. 2 Vols. Report of Investigations No. 60. Archeological \& Environmental Consultants, LLC, Austin.

Shafer, H. J. and M. Walters

2010 The Browning Site (41SM195A) Lithics: Considering Patterns of Identity and Interaction through Lithic Analysis. Bulletin of the Texas Archeological Society 81:127-151.

Story, D. A.

1990 Cultural History of the Native Americans. In The Archeology and Bioarcheology of the Gulf Coastal Plain, by D. A. Story, J. A Guy, B. A. Burnett, M. D. Freeman, J. C. Rose, D. G. Steele, B. W. Olive, and K. J. Reinhard, pp. 163-366. Research Series No. 38. 2 Vols. Arkansas Archeological Survey, Fayetteville.

Tunnell, C. D.

1961 Evidence of a Late Archaic Horizon at Three Sites in the McGee Bend Reservoir, San Augustine County, Texas. Bulletin of the Texas Archeological Society 30:123-158.

Webb, C. H., F. E. Murphey, W. G. Ellis, and H. R. Green

1969 The Resch Site, 41HS16, Harrison County, Texas. Bulletin of the Texas Archeological Society 40:3-106. 